\title{
Analysis of the self-archiving policies of journals in the highest rank category of the Finnish journal classification system within computer science, physics and electronic engineering
}

\author{
Antti M. Rousi \\ Research and Innovation Services, Aalto University \\ antti.m.rousi@aalto.fi \\ https://orcid.org/0000-0002-4184- 7035
}

Vaikka avointen lehtien määrä on nousussa, vaikuttaa maksumuureihin perustuva toimintamalli olevan edelleen tieteellisen julkaisemisen modus operandi. Täten suurin osa julkaisuista voidaan avata (open access) joko maksamalla kustantajille yksittäisten artikkelien avoimuudesta tai rinnakkaistallentamalla työ avoimeen julkaisuarkistoon kustantajan ehtojen mukaisesti. Keskeistä on, miten kustantajat suhtautuvat avoimuuteen ja mitä ne tässä suhteessa sallivat. Miten on huippulehtien laita? Sallivatko Julkaisufoorumi-luokituksen arvostetuimmat lehdet maksuttoman avoimen rinnakkaistallentamisen ja millä ehdoilla? Tämä katsaus tarkastelee Julkaisufoorumissa korkeasti arvostettujen tietotekniikan, fysiikan ja sähkö-, automaatio- ja tietoliikennetekniikan lehtien rinnakkaistallennusehtoja. Rinnakkaistallennusehtoja tarkastellaan suhteessa Euroopan Tutkimusneuvoston avoimen julkaisemisen vaatimuksiin. Tarkastelun fokus on hyväksyttävissä versiotyypeissä ja embargojaksojen pituuksissa. Julkaisuarkistojen osalta rinnakkaistallennusehtoja tarkastellaan suhteessa yliopisto- ja tieteenalakohtaisia julkaisuarkistoja koskeviin ehtoihin. Analyysin tuloksena on, että noin $75 \%$ tarkastelluista lehdistä sallii rinnakkaistallennuksen joko yliopisto- tai tieteenalakohtaisiin julkaisuarkistoihin siten, että Euroopan Tutkimusneuvoston vaatimukset versiotyypeistä ja embargojaksojen pituuksista täyttyvät. Katsauksen aineisto on avoimesti saatavilla.

Asiasanat: tutkimus- ja kehittämistoiminta; tiedepolitiikka; tieteellinen julkaisutoiminta; rinnakkaisjulkaiseminen; tutkimusrahoitus

Within the context of Finland, both national and international research funders are posing increasing demands on the openness of funded research. Publishing in open journals, opting for the hybrid model of paying for the openness of single articles and self-archiving copies to open repositories are all methods of 
creating open access (see Academy of Finland, 2017; European Commission, 2017). Even though the amount of open access journals is increasing, paywall journals still appear as the modus operandi of scientific publishing. This suggests that the options for opening the majority of scientific outputs are narrowed to either paying for the openness of single articles or to open self-archival in compliance to the terms set by the publishers. The key factor is how the scientific publishers align themselves with regard to open access. What about the most esteemed journals? Do the top-ranked journals in the Finnish Publication Forum classification (Finnish Federation of Learned Societies, 2018) allow open self-archiving and with what terms? Or is it necessary to opt for the costs of hybrid model openness, if one looks to publish in the top journals while working in European Research Commission funded projects, for example?

This short review examines self-archiving polices of Publication Forum topranked journals representing the field of sciences of computer science, physics and electronic engineering. Self-archiving policies are examined from the viewpoint of the version and embargo requirements of open access publishing presented in European Research Commission's H2020 Model Grant Agreement (European Commission, 2017). The journals representing the field of sciences in focus were identified by using the Field of science, Statistics Finland indicators assigned to journals in the Publication Forum's publication channel search (see Finnish Federation of Learned Societies, 2018). As the H2020 Model Grant Agreement states that acceptable types of online repositories may vary (see European Commission, 2017, p. 237), a decision was made to focus this short review into self-archiving policy terms concerning subject and institutional repositories. The fields of science of computer science, physics and electronic engineering were of professional interest of the author as they constitute as some of the most prominent fields of publishing in the author's university.

\section{Terminology}

The terminology used in this review is based largely on Laakso's (2014, p. 482) publisher policy coding framework and is further specified here. Fully open journal (often referred to as gold open access) refers to a fully open access journal. Hybrid journal refers to a journal with a business model based on both subscription fees for pay-walled content and article processing charges for open availability of single articles. In hybrid model journals open access articles are often limited to those where the separate open access charge has been paid. Institutional repository refers to research-institution specific open repository that collects and openly disseminates research outputs created in the 
institution often on a non-commercial basis. Subject repository refers to a field of science- or topic specific open repository that collects and openly disseminates research outputs also on a non-commercial basis. Preprint refers to version of a scientific work as it was at the time it was first sent to a journal, i.e., pre-peer review version of a work. Accepted manuscript (also final draft or post-print) refers to the post-peer review version of the work as it was before the publisher created the final layout for the work. Publisher version (also final PDF) refers to the scientific work in the form in which the publisher disseminates it. Selfarchiving (often referred to as green open access) refers to making a version of the work openly available through an open repository, such as university's institutional repository or subject repository, in compliance with the publisher's policy terms on self-archival. Embargo refers to the potentially prescribed time delay set by the publishers to restrict open access release of the work and as a term is most often used by the publishers when defining the policy terms on selfarchival. The purpose of embargo periods may be seen to reserve the exclusive right to disseminate the published work for a certain peri od of time even though open dissemination of, for example, the accepted manuscript would eventually be allowed from institutional repositories.

To the author's best knowledge, no publisher currently poses a fee on open self-archival of their content when done in compliance with their policies. At least this was the case with the publishers whose journals were examined in this review. However, the terms of self-archival vary, such as the allowed version types, allowed repository types and embargo periods set to open release of content (see Gadd \& Covey, 2016; Laakso, 2014).

\section{Background and literature review}

\section{The Grant Agreement of European Research Commission's Horizon2020 program}

The requirements of open access publishing of the European Commission are specified in the H2020 Model Grant Agreement. The H2O20 Model Grant Agreement states that "Each beneficiary must ensure open access (free of charge, online access for any user) to all peer-reviewed scientific publications relating to its results." The section 29.2 of the Model Grant Agreement further specifies that "In particular, it must: (a) as soon as possible and at the latest on publication, deposit a machine-readable electronic copy of the published version or final peer-reviewed manuscript accepted for publication in a repository for scientific publications". Within the Model Grant Agreement, also acceptable embargo 
periods are referred to as follows: "(b) ensure open access to the deposited publication - via the repository - at the latest: (i) on publication, if an electronic version is available for free via the publisher, or (ii) within six months of publication (twelve months for publications in the social sciences and humanities) in any other case." (see European Commission, 2017)

As stated previously, self-archiving policies are examined from the viewpoint of the version and embargo requirements of open access publishing presented in European Research Commission's H2020 Model Grant Agreement. For journals representing computer science, physics and electronic engineering, these requirements are seen as follows: open access to either accepted manuscript or publisher version via an open repository with a maximum embargo of six months.

\section{The Publication Forum classification}

Publication Forum (Julkaisufoorumi in Finnish) is a classification of publication channels created by the Finnish scientific community to support the quality assessment of academic research. The classification rates both foreign and domestic publication channels including journals and serials, conferences and book publishers. The classification is comprised of three levels: $1=$ basic; 2 $=$ leading and $3=$ top. The evaluations of the publications channel are done by expert panels consisting of Finnish or Finland-based scholars (For more information on the classification, see Finnish Federation of Learned Societies, 2018). ${ }^{1}$

Within this review, the journals representing the fields of computer science, physics and electronic engineering were identified using the Field of science, Statistics Finland indicators assigned to journals in the Publication Forum classification. It is important to note that these field of science indicators are not assigned to journals by the Publication Forum expert panels. According to information on the Publication Forum publication channel search, "journals scientific fields have been defined by combining Web of Science and Scopus classification, as well as those used in the Norwegian and Danish rating systems and the European Reference Index for the Humanities" (Finnish Federation of

1 It is possible to examine the so-called SHERPA/RoMEO "colours" of journals listed in Publication Forum (see JISC, 2018) directly from Publication Forum's publication channel search. The purpose of the SHERPA/RoMEO colours is to suggest an outline of the journals' self-archiving policy. However, the SHERPA/RoMEO colour classification does not include the following information of publisher policies relevant to this review: the length of a possible embargo period and accepted repository types. For more about the shortcomings of the Sherpa colour classification, see Gadd and Covey (2016). 
Learned Societies, 2018). The amount of highest ranking journals representing the different fields varied substantially when identified using the Field of science indicators (from 85 journals ranked level 3 classified under ' 113 Computer science' compared to only 39 level 3 journals classified under ' 213 Electronic, automation and communications engineering' and 32 journals level 3 journals classified under ' 114 Physics'). However, the aim of this review was is not to effectively compare these distributions but to provide a field-specific overview of highest ranked journals' policies regarding open self-archival.

\section{Studies on open self-archival policies}

Journals' policies regarding open self-archival have been previously studied most often through large multidisciplinary approaches (e.g. Laakso, 2014). There are also some previous field of science specific studies where the policies of journals having highest Thomson Reuters' journal impact factors have been examined (e.g. Laakso \& Lindman, 2016). In addition, there are accounts that showcase the dynamic and changing nature of the publishers' self-archiving policies (Gadd \& Covey, 2016) Also, scientific impact of open access and paywall journals in general have previously been studied also using the journal impact factor indicator (e.g. Björk \& Solomon, 2012; Gumpenberger, OvallePerandones, \& Gorraiz, 2013). However, there currently appears not to be domain specific studies regarding self-archival policies of top-ranked scientific journals representing the fields of computer science, physics and electronic engineering where scientific impact is approached through the Finnish Publication Forum classification.

\section{Research design}

\section{Subject and institutional repositories}

As the H2020 Model Grant Agreement states that acceptable types of online repositories may vary (see European Commission, 2017, p. 237), a decision was made to focus this short review into self-archiving policy terms concerning subject and institutional repositories. This was done on the basis that both established non-commercial subject and institutional repositories were viewed as likely more compliant repositories from the viewpoint of the terms $\mathrm{H} 202 \mathrm{O}$ Model Grant Agreement. Within the current context there appears to be technical dimensions, such as machine-readable metadata and persistent identifiers, which may restrict the use of personal websites of the final archival site of funded research (see European Commission, 2017, pp. 234-235). Respectively, 
copyright dimensions may be seen to hinder utilising commercial repositories and services as the site of open self-archival of post-peer review research content (see e.g. Laakso, 2014; Rousi, 2016). The author acknowledges that both subject and institutional repositories may vary in their readiness to comply with the details of the H2020 Model Grant Agreement. However, the focus of the present review is on publishers' policies regarding self-archival, not on analysis whether individual repositories meet the demands of $\mathrm{H}_{2020}$ Model Grant Agreement or not.

\section{Research questions}

The research questions of the present review are posed as follows. What is the percentage of hybrid journals of all Publication Forum level 3 journals having the Field of science indicators of computer science, physics and electronic engineering? And what is the self-archiving policy of the previous hybrid journals regarding openly disseminating content from either institutional or subject repositories? With regard to the self-archiving policies, the present short review scrutinises the following matters in detail. Which version of the scholarly work may be openly archived in either institutional or subject repositories? And what are the durations of embargoes posed on openly archiving these versions to the previous repository types? Once journal policies are analysed in the aforementioned ways, it is possible to reflect the findings from the viewpoint of the European Commission's H2020 Model Grant Agreement's version and embargo requirements.

\section{Methodology}

The Publication Forum level 3 journals representing the fields of science of computer science, physics and electronic engineering were identified by utilising the MinEdu field search filter while searching in the Publication Forum's publication channel search (see Finnish Federation of Learned Societies, 2018). Minedu field search filter is based on Field of Science, Statistics Finland classification (see Statistics Finland, 2018). The journal data was gathered in August 2017 and it consists of 127 individual journals. It is worth noting that circa 30 Publication Forum level 3 journals had more than one of the Field of science indicators of computer science ('Computer Science 113'; 85 journals), physics ('Physics 114'; 32 journals) or electronic engineering ('213 Electronic, automation and communications engineering'; 39 journals). First, the extracted 
journal data were divided into representing either fully open or hybrid model journals. Second, self-archiving policies of the identified hybrid journals were analysed utilising Laakso's (2014, p. 482) publisher policy coding framework (see Listing 1). Policies of individual journals were examined so that each data point of Laakso's (2014, p. 482) framework were given either yes or no values (see Rousi, 2017). Also publishers of the individual journals were identified and subsequently added to the data.

It is important to note that the data of the present review includes only the shortest embargo policy regardless whether these terms are set for institutional or subject repositories. Elsevier, for example, posed embargoes to opening content from institutional repositories, but had no embargoes to opening post-peer review content from subject repositories (e.g. arXiv). Therefore, Elsevier's journals are within this review categorized as having no embargoes. As analysing publishers' self-archiving policies requires interpretation, the aggregated data were published as a spreadsheet to ensure transparency of the findings (see Rousi, 2017). The publishers' policies, which may be subject to change, were interpreted in August 2017. After the analysis of the self-archiving policies was completed, the data were summarised per field of science.

\section{- Preprint}

- Explicit policy available

- Preprint permitted

- Location

* Personal website

* Institutional repository

* Subject repository

* Elsewhere online with free access

\section{- Accepted manuscript}

- Accepted manuscript permitted

- Embargo

* 6 months

* 12 months

* 18 months

* 24 months 
- Location

* Personal website

* Institutional repository

* Subject repository

* Elsewhere online with free access

- Publisher version

- Published article permitted

- Embargo

* 6 months

* 12 months

* 18 months

* 24 months

- Location

* Personal website

* Institutional repository

* Subject repository

* Elsewhere online with free access

Listing 1: Laakso's $(2014,482)$ publisher policy coding framework.

\section{Findings}

\section{Fully open journals vs. hybrid journals}

The percentage of fully open journals was diminutive within the level three ranked journals having the Field of science indicators of computer science, physics and electronic engineering (see Figure 1). Physics related journals had the highest percentage of fully open journals within highest ranked ones, but the amount still appears as not so significant (6\%). Thus, within the top Publication Forum ranked journals classified to computer science, physics and electronic engineering, the hybrid model still appears as the prevalent business logic.

\section{Hybrid journals' policies on self-archiving peer-reviewed content to either subject or institutional repositories}

For purposes of examining the policies regarding open self-archival of peerreviewed content of the hybrid journals in focus, the data were aggregated so that journals were categorised into three following categories: 1) accepted 

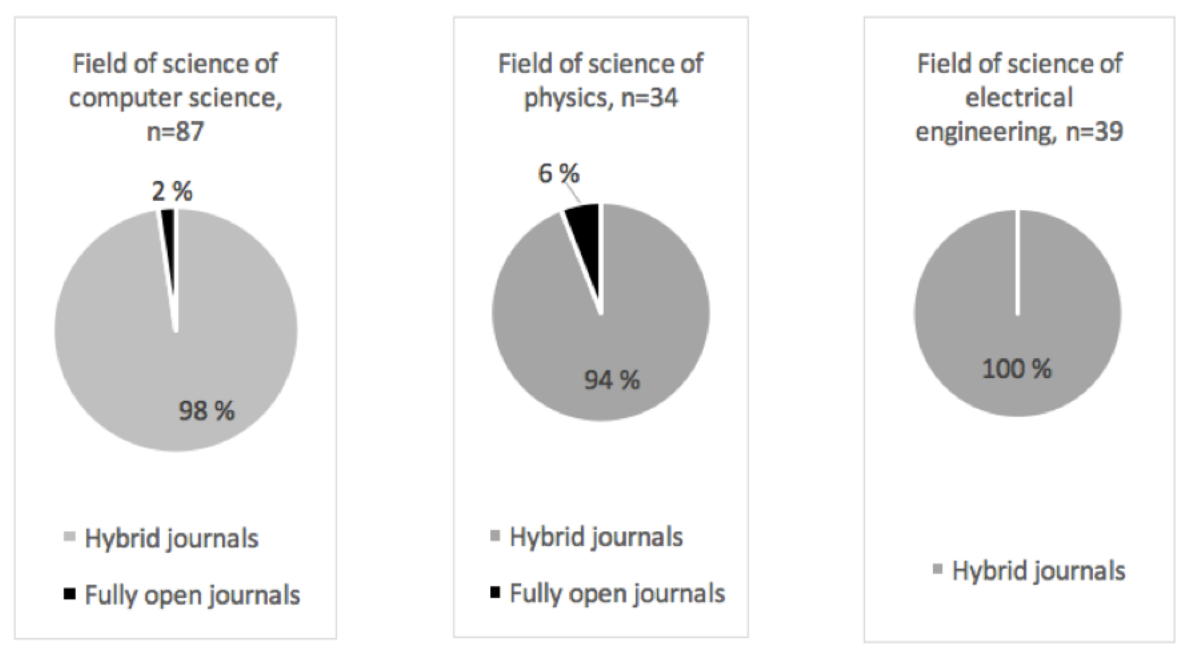

Figure 1: Hybrid journals with a Publication Forum classification 3 and classified under field of sciences of computer science, physics and electronic engineering - Fully open journals vs. hybrid journals.

manuscript or final published PDF may not be archived into either subject or institutional repositories, 2) accepted manuscript may be openly archived into either subject or institutional repositories and 3) final published PDF may be openly archived into either subject or institutional repositories. As result, it appears that nearly all of the journals allow opening of either accepted manuscript or final published PDF from the above repository types (see Figure 2). The only journals within the data that did not allow the opening of post-peer review content from the repository types in focus were Annual review of nuclear and particle science and Annual review of fluid mechanics. However, the previous two journals allowed the opening of pre-prints (ie. pre-peer review versions) from, e.g., institutional repositories. Based on the findings of this review, it appears that highly ranked journals of the fields in focus are lenient towards openly self-archiving peer-reviewed content to either subject or institutional repositories (see Figure 2).

\section{Embargoes set for self-archiving accepted manuscripts into either subject or institutional repositories}

An essential factor regarding the terms of self-archival set by the publishers is the embargo or delay time set by the publishers. For the purposes of examining the embargo periods set by the journals in focus for open archival of accepted 

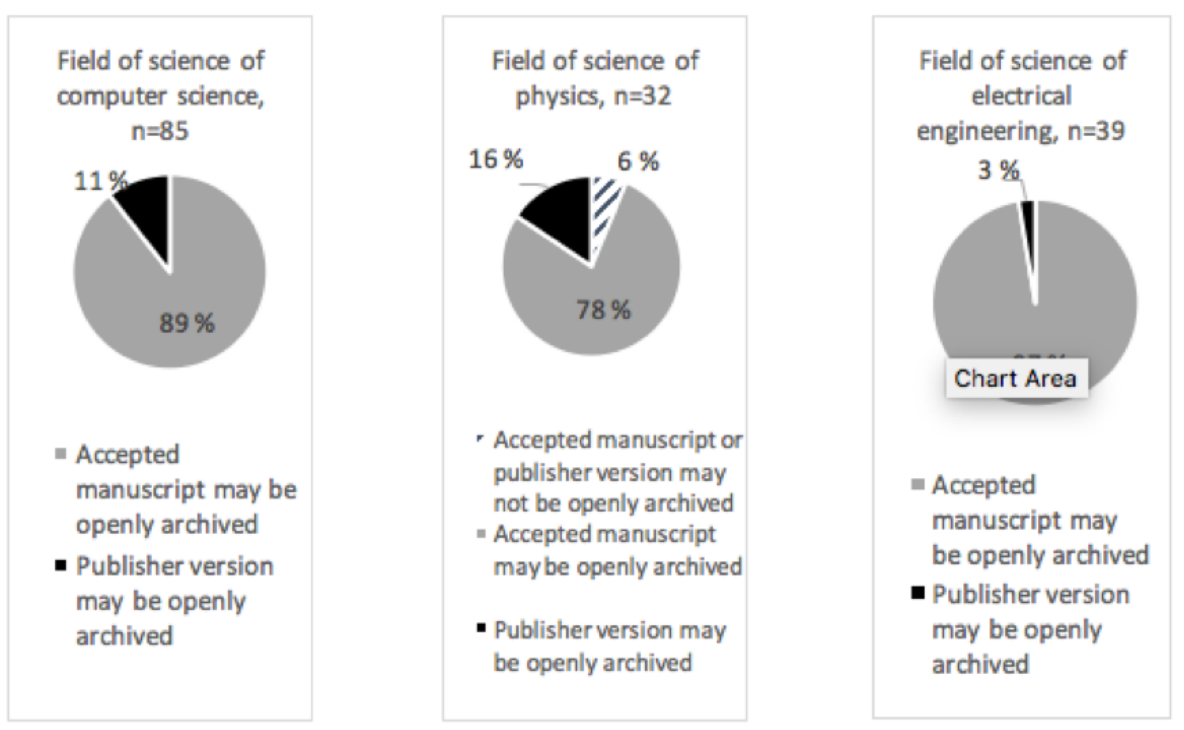

Figure 2: Hybrid journals with a Publication Forum classification 3 and classified under field of sciences of computer science, physics and electronic engineering - policy on openly archiving peer-reviewed content to either subject or institutional repositories.

manuscripts, the hybrid journals within the data were further classified as follows: 1) accepted manuscript cannot be openly archived into either subject or institutional repositories, 2) no embargo period set for opening of content from either one of the above repository types, 3) embargo of 6 months, 4) embargo of 12 months, 5) embargo of 18 months and 6) embargo of 24 months (see Figure 3).

The results are that approximately $75 \%$ of the hybrid journals within the data allow open archival of post-peer review content from either subject or institutional repositories with an embargo of 6 months or with no embargo at all. When examining the data as a whole, a notable result is also that circa $67 \%$ of all hybrid journals in focus allow the opening of the accepted manuscript from either one of the above repository types without an embargo. Elsevier appears as the lone publisher in the present review's data that poses embargoes for opening content from institutional repositories but allows immediate open self-archival of post-peer review content into arXiv and RePec, which here are classified as subject repositories (Elsevier, 2017). All other publishers were embargo-wise either more lenient towards opening of content from institutional repositories or the embargo terms concerning these two repository types were the same. Circa $23 \%$ of all journals in scrutiny were published by Elsevier. 

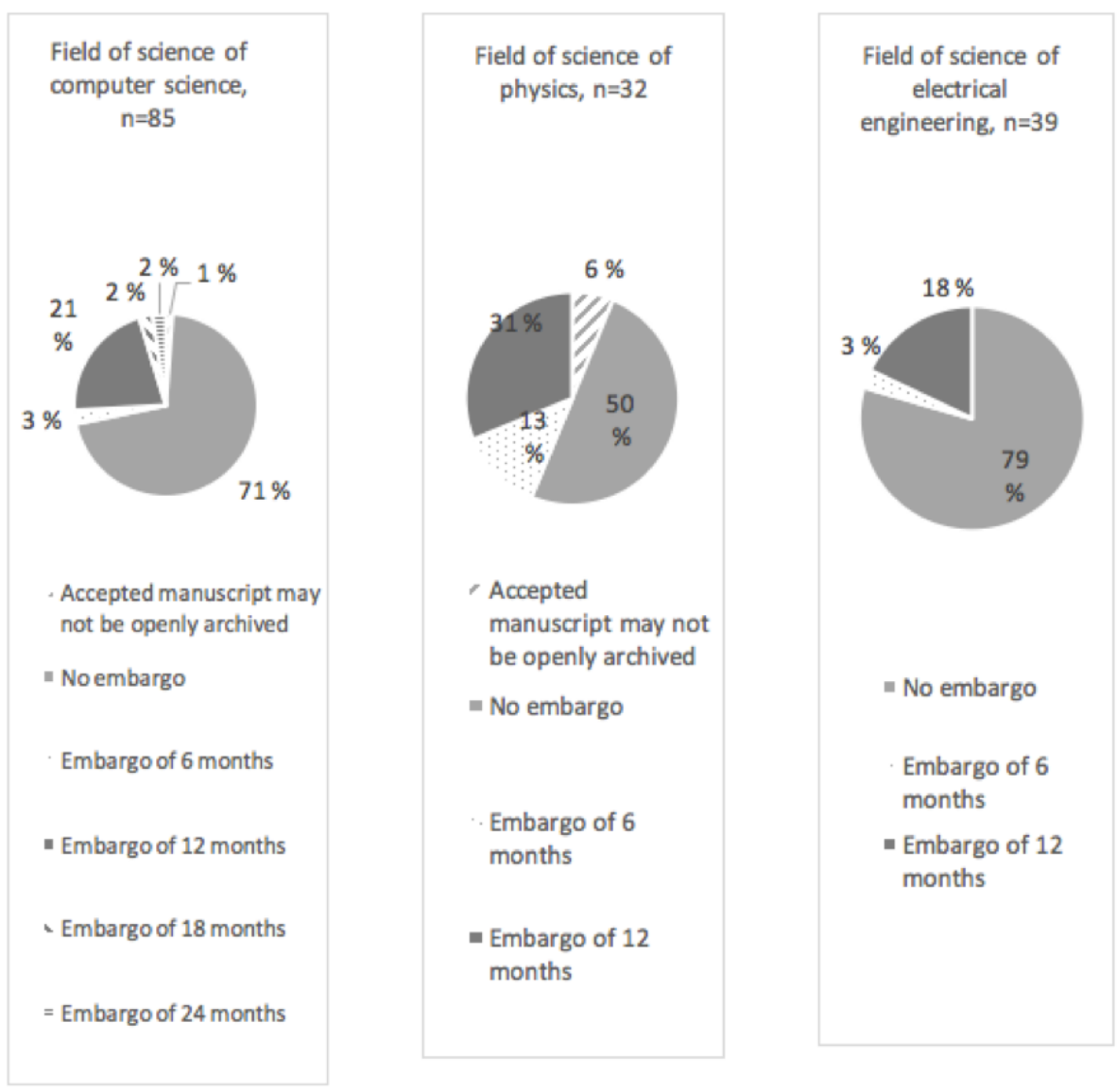

Figure 3: Hybrid journals with a Publication Forum classification 3 and classified under field of sciences of computer science, physics and electronic engineering - embargoes of openly archiving accepted manuscripts into either subject or institutional repositories. 


\section{Embargoes set for self-archiving publisher versions into either subject or institutional repositories}

As presented in Figure 2, some of the hybrid journals in focus allowed also the opening of the publisher versions from either subject or institutional repositories. For the purposes of examining the embargo periods set by the publishers in focus on open archival of publisher versions, the hybrid journals within the data were further classified as follows: 1) publisher version cannot be opened from either subject or institutional repositories, 2) no embargo posed on opening of publisher versions from either one of the above repository types, 3) embargo of 3 months, 4) embargo of 6 months, 5) embargo of 12 months and 6) embargo of 60 months (see Figure 4).

The results presented in Figure 4 highlight that publishers of the top hybrid journals of the fields of sciences of focus are not lenient what comes to open self-archival of publisher versions to subject or institutional repositories. The amount of journals that allowed this ranged from 3\% to $15 \%$ between journals representing the fields of sciences in scrutiny. The amount of journals that allow open archival of the publisher versions with a 6 month embargo or with no embargo at all, ranged from $12 \%$ (physics) to $3 \%$ (electrical engineering). MIS quarterly was the only journal within the data of the present review that allowed the publisher PDF to be openly self-archived but not the accepted manuscript nor the pre-print version. However, MIS quarterly posed an embargo of five years for the self-archival of the publisher version, so it's policy does not affect the approximation of journals' self-archiving policies compliant to the $\mathrm{H}_{2} \mathrm{O} 2 \mathrm{O}$ Model Grant Agreement's version and embargo requirements suggested in Figure 3 .

\section{Discussion}

The diminutive amount of fully open journals in the highest rank category of the Finnish journal classification journals or the publishers' leniency towards open self-archival are as such hardly new results. However, this review verifies that this is these apply also to the Finnish Publication Forum top-ranked journals representing computer science, physics and electronic engineering. Based on the findings of this review, it appears that highly ranked hybrid journals representing the above fields of science are on average lenient towards open self-archival into either subject or institutional repositories. Circa $75 \%$ of the hybrid journals in focus allowed either immediate open archival of post-peer review content or posed only six month long embargoes. This suggests that selfarchiving is a valid option for researchers publishing in these highest ranked 

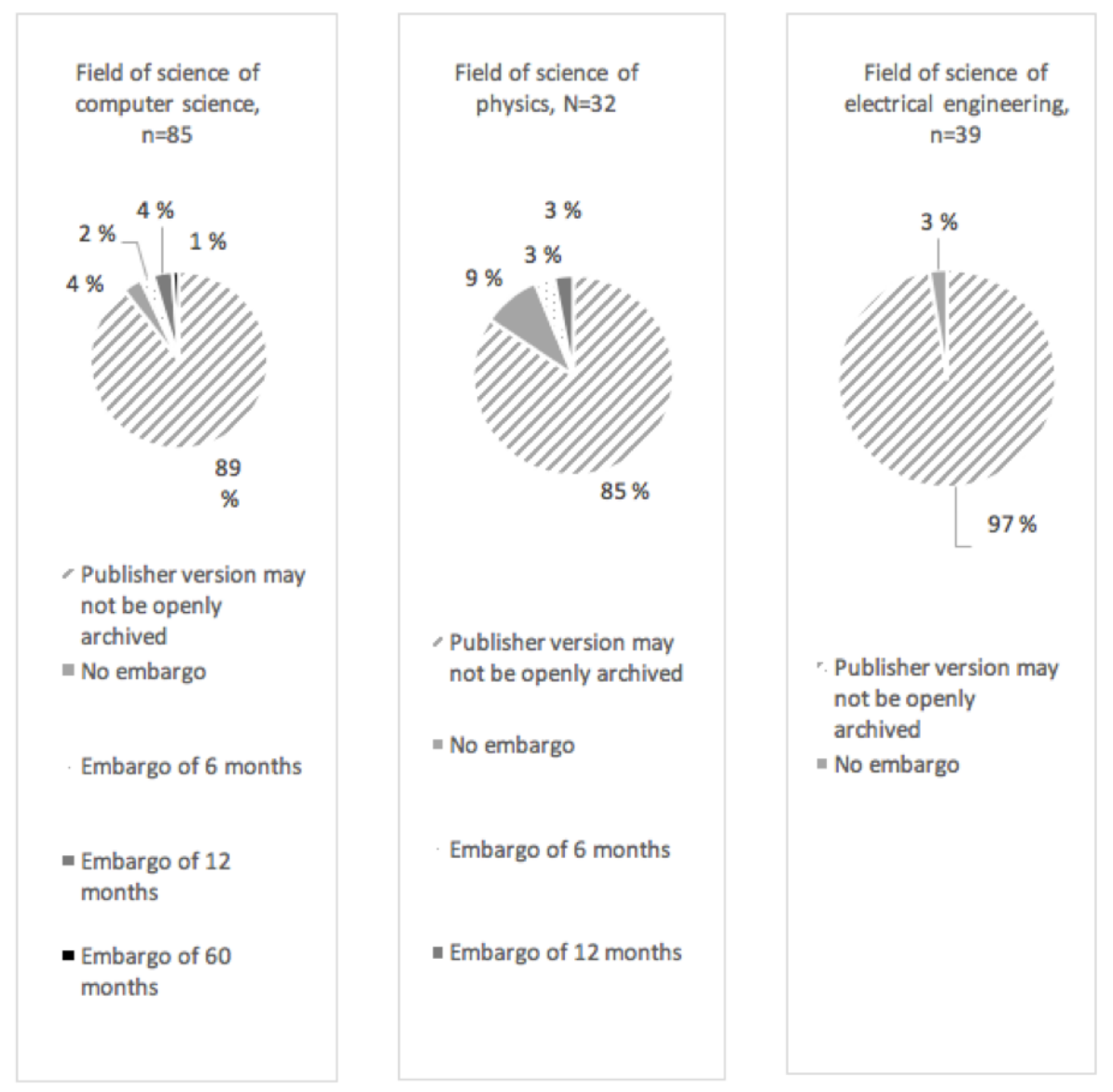

Figure 4: Hybrid level three journals classified under field of sciences of computer science, physics and electronic engineering - embargoes of openly archiving final PDFs into either subject or institutional repositories. 
journals while working in a European Commission funded projects. This is relevant as research funders are posing increasing demands on open availability of funded research and only three percent of all of the journals ranked at level three and having one of the above Field of science indicators were considered as fully open journals.

The amount of journals that comply with the H2020 Model Grant Agreement's version and embargo requirements appears higher with the journals in focus of the present review when compared to the aggregated data from several field of sciences. In comparison, Laakso (2014, p. 409) has calculated that when approaching the matter through the 100 largest scientific publishers, about $55 \%$ of journals have an embargo of 6 months or no embargo at all to opening works from either subject or institutional repositories. It is important to note, however, that both Publication Forum classifications and publishers' policies on open selfarchival are subject to change.

It is important to further stress that within this review, the field of sciences of journals were identified using the Field of science, Statistics Finland indicators assigned to journals in the Publication Forum publication channel search. As stated previously, these indicators are derived from field of science classifications used in international reference databases Web of Science and Scopus database and of those used in Norwegian and Danish journal rating systems. The apparent downside of using these indicators to identify journals representing a certain field of science is that the amount of journals having individual Field of science indicators seems to vary substantially. However, the fact that this examination was not linked to the journal groups assessed by individual expert panels may also be seen of the following value. Researchers working in multidisciplinary oriented fields, such as computer science, may be interested in also journals that are not assessed by the field specific expert panel. Furthermore, the amount of top-ranked journals that were under scrutiny in this review most likely exceeds the top journal quotas given to the field specific expert panels. Thus, the review provides a broader view on self-archiving policies of top-ranked journals. The list of journals that were included in this review is openly available (see Rousi, 2017).

Laakso's (2014, p. 482) publisher policy framework worked well for the purposes of the present review. The only modification made to it was in the publisher versions' embargo periods where a data point of 60 months embargo was added. As stated previously, the data and interpretations within it are open for scrutiny (see Rousi, 2017). 


\section{References}

Academy of Finland. (2017). Open science: Open access publishing and open data. http://www. aka.fi/en/funding/responsible-research/open-science/ (luettu 04/06/2018)

Björk, B.-C., \& Solomon, D. (2012). Open access versus subscription journals: A comparison of scientific impact. BMC Medicine, 10, 73. https://doi.org/10.1186/1741-7015-10-73

Elsevier. (2017). Article sharing policy. https://www.elsevier.com/about/our-business/ policies/sharing (luettu 04/10/2018)

European Commission. (2017). Horizon202o programme - annotated model grant agreement. Version 4.1. http://ec.europa.eu/research/participants/data/ref/h2020/grants_manual/ amga/h2020-amga_en.pdf

Finnish Federation of Learned Societies. (2018). Publication forum [publication channel search included]. http://www.julkaisufoorumi.fi/en

Gadd, E., \& Covey, D. T. (2016). What does "green" open access mean? Tracking twelve years of changes to journal publisher self-archiving policies. Journal of Librarianship and Information Science, 0961000616657406. https://doi.org/10.1177/0961000616657406

Gumpenberger, C., Ovalle-Perandones, M.-A., \& Gorraiz, J. (2013). On the impact of gold open access journals. Scientometrics, 96(1), 221-238. https://doi.org/10.1007/s11192-012-09027

JISC. (2018). SHERPA/romeo - definitions and terms. http://www. sherpa.ac.uk/romeo/ definitions.php (luettu 04/17/2018)

Laakso, M. (2014). Green open access policies of scholarly journal publishers: A study of what, when, and where self-archiving is allowed. Scientometrics, 99(2), 475-494. https://doi.org/ $10.1007 / \mathrm{s} 11192-013-1205-3$

Laakso, M., \& Lindman, J. (2016). Journal copyright restrictions and actual open access availability: A study of articles published in eight top information systems journals (2010-2014). Scientometrics, 109(2), 1167-1189. https://doi.org/10.1007/s11192-016-2078-z

Rousi, A. (2016). Essay on institutional repositories and open access. Informaatiotutkimus, 35(12), 22-28. https://journal.fi/inf/article/view/58980 (luettu 04/06/2018)

Rousi, A. M. (2017). Data of the article analysis of the self-archiving policies of journals in the highest rank category of the finnish journal classification system within computer science, physics and electronic engineering. Zenodo. http://doi.org/10.5281/zenodo.1119181 (luettu 04/06/2018)

Statistics Finland. (2018). Field of science 2010 classification. https://www.stat.fi/meta/ luokitukset/tieteenala/001-2010/index_en.html 